\title{
Citizen involvement in scientific activities and extension of knowledge to society
}

\author{
Envolvimento do cidadão nas atividades científicas e extensão do conhecimento à sociedade \\ Intervención del ciudadano en actividades científicas y extensión del conocimiento \\ a la sociedad
}

How to cite this article:

Silva RCG, Cardoso DFB, Cardoso MLS, SÁ MCGMA, Apóstolo JLA. Citizen involvement in scientific activities and extension of knowledge to society. Rev Esc Enferm USP. 2021;55:e20210171. https://doi.org/10.1590/1980-220X-REEUSP-2021-0171

\section{Rosa Carla Gomes da Silva ${ }^{1,2}$ \\ Daniela Filipa Batista Cardoso ${ }^{1,2}$ \\ Maria Lucília da Silva Cardoso ${ }^{1}$ \\ Maria da Conceição Gonçalves Marques Alegre de Sá ${ }^{1}$ \\ (D) João Luís Alves Apóstolo ${ }^{1,2}$}

${ }^{1}$ Health Sciences Research Unit: Nursing (UICISA: E), Nursing School of Coimbra (ESEnfC), Portugal.

${ }^{2}$ Portugal Centre for Evidence Based Practice: a Joanna Briggs Institute Centre of Excellence, Coimbra, Portugal.

\begin{abstract}
High-quality health research must involve the citizen, bringing merit, relevance, and value to research and ensuring the transfer of new knowledge or outputs to the community. This theoretical study aimed to conceptualize and discuss the role of Citizen Involvement and Extension to Society in research processes and outcomes, revealing that both concepts have different purposes. Research units and research funding agencies are promoting Citizen Involvement in all steps of the research process because it adds quality to it. Moreover, universities, research units, and researchers should extend their knowledge to society, the citizens, or the end-users as part of their social responsibility. Citizen Involvement and Extension to Society should be considered strategic areas for the development of research in general and nursing research in particular. More studies are needed to generate new knowledge and useful products to better serve the real needs of society.
\end{abstract}

DESCRIPTORS

Citizen Science; Community Participation; Community-Institutional Relation. 


\section{INTRODUCTION}

For the promotion of citizen literacy and societal development, universities and research units should commit to a broader understanding of their scientific priorities while society is asked to have greater knowledge about research outcomes and greater understanding of science.In addition, policymakers should increasingly have the possibility to give citizens the power to make decisions in matters of public interest, providing spaces and instruments that facilitate and encourage such participation ${ }^{(1)}$.

The evolution of the culture of science communication and citizen involvement differs across countries, depending on their level of development. The most developed countries usually have well-organized and structured public participation and science communication processes ${ }^{(1)}$. In their turn, the least scientifically developed countries usually have incipient public participation processes, still based on a logic of scientific knowledge dissemination with little or no citizen participation in decision-making in matters of public interest ${ }^{(2)}$.As the development of a country and a society largely depends on the maturity of scientific and technological development, it is essential to reflect on how this development occurs, particularly concerning Citizen Involvement in research projects and Extension of knowledge to Society.

Therefore, this theoretical article aims to conceptualize and discuss the role of Citizen Involvement and Extension to Society in research processes and outcomes based on a theoretical analysis supported by relevant scientific evidence on the central concepts and consequent theoretical reflection.

\section{Citizen Involvement}

There is increasing interest in involving lay (nonspecialist) citizens in scientific activities, particularly in encouraging their participation in debates related to scientific research and technological development (SR\&TD) activities as a strategy to better respond to real-life issues and needs ${ }^{(3,4)}$.

Concerning the concept of Citizen Involvement, the several classifications used internationally lead to a lack of understanding. Some examples found in the literature include patient and public involvement, citizen engagement, citizen science, citizen participation, community engagement, consumer involvement, public adviser, public involvement, and volunteered geographic information ${ }^{(3-6)}$. Despite these terminologies, Citizen Involvement can be generally defined as any activity that directly or indirectly contributes to the design and development of SR\&TD projects ${ }^{(5)}$. In health research, a member of society is any citizen, such as actual or potential patients, caregivers, family members, health service users, or patient representatives like associations or non-governmental organizations (NGOs). Therefore, it is a key area for the development of responsible research and innovation (R\&I), bringing together several stakeholders who usually do not interact with each other, such as researchers, politicians, civil society, industries, NGOs, and citizens, to discuss and deliberate on concerning of ethics, science, and technology ${ }^{(6-9)}$.
The involvement in the design and development of SR\&TD projects is expected to promote a dialogue among academics, researchers, and citizens through participatory interaction with project stakeholders, who, in turn, will foster greater understanding among these different actors. This project development methodology can also promote the co-creation of research results with greater value and more innovation, and in doing so will provide new inputs for the policy agendas ${ }^{(9)}$. Citizen Involvement also promotes the opportunity to reflect on issues loaded with ethical values, while fostering inclusion, transparency, diversity, and creativity ${ }^{(9)}$. This involvement of citizens in research means conducting research "with" rather than conducting research "for" or "on" people ${ }^{(4,5,8)}$. Therefore, Citizen Involvement in research processes differs from the role of participants to the extent that the latter are part of the study sample and recruited, for example, to provide data by completing a questionnaire or taking part in a focus group or clinical trial ${ }^{(4,5,8)}$.

Thus, based on existing models, the level of Citizen Participation or Involvement in the research processes, steps, or activities can be divided into three categories: (i) Contributory; (ii) Collaborative; or (iii) Co-created ${ }^{(10)}$. Contributory projects are generally designed by scientists and for which citizens primarily contribute with data, thus being participants. Collaborative projects are generally designed by scientists and for which citizens contribute with data and also help refine project design, analyze data, or disseminate new knowledge/products. Co-created projects, also called co-design and co-validation projects, imply joint work between researchers and scientists and where citizens are actively involved in most or all steps of the project ${ }^{(3,10)}$.

Until the end of the $19^{\text {th }}$ century, before the professionalization of science, most research was conducted by amateur citizens who became recognized experts in their field ${ }^{(11)}$. In addition, there was a collaboration between citizens and academics, for example, in ecological research, with renowned researchers such as John Ray (1670-1705) and Carl Linnaeus (1707-1778) recruiting citizens to help in the collection and observation of specimens worldwide ${ }^{(11)}$. These contributions by trained citizens have helped build some of the most valuable collections of animals, plants, rocks, fossils, artifacts, and other specimens ${ }^{(11)}$. Today, the contribution of citizens remains an essential tool, for example, for the development of ecological knowledge. One of the best examples is ornithology research, where citizens help researchers understand many issues, such as how emerging infectious diseases spread through wild bird populations ${ }^{(12)}$.

In the health area, the major milestones began in the United Kingdom. The Medical Research Council (MRC) Clinical Trials Unit at the University College London (UCL) has published its Guidelines for Good Clinical Practice in Clinical Trials and systematic reviews, where they recommend Citizen Involvement in the several steps of the research process. Thus, in these guidelines, this involvement is recommended at the level of the commissions responsible not only for the design of clinical trials/systematic reviews but also for the collaboration in dissemination, including 
the development and distribution of citizen information materials $^{(13,14)}$.

The United Kingdom, therefore, has a long tradition in this matter ${ }^{(4)}$. The National Institute for Health of the National Health Service (NHS) recognizes the value of Citizen Involvement in the various steps of the research process, based on its SR\&TD activities over the years ${ }^{(13-15)}$. However, this research development method, that is, involving the citizen in the various steps, from design to implementation and dissemination, is nowadays used by relevant international institutions such as the National Institutes of Health (NIH) Director's Council of Public Representatives ${ }^{(16)}$ in the United States and the Cochrane Collaboration Consumer Network ${ }^{(17)}$.

\section{HOW TO IMPLEMENT CITIZEN INVOLVEMENT}

Citizen Involvement is still very low globally, and it is estimated to include less than three million citizens to date ${ }^{(18)}$. One of the challenges of this involvement may be the citizens' motivation to participate given that this work is usually voluntary ${ }^{(3,4,18)}$. On the other hand, citizens can perceive participation in after-work activities as a challenging opportunity for intervention in a social world that should be shared ${ }^{(3,4)}$. Voluntary work is a lifestyle that provides identities to people and can also be viewed as behavioral expressions of their central life interests ${ }^{(5)}$. From another perspective, patients, patient associations, and other civil society organizations have intrinsic motivations regarding participation in matters of their interest. One example is the creation of platforms that share innovative user-created solutions, such as Patient Innovation ${ }^{(19)}$.

Studies have shown that citizens must be involved from priority setting to the dissemination of findings so as to maximize their contributions to the research process or the business network ${ }^{(20)}$. Thus, citizen involvement in both research and businesses implies restructuring and reorganizing researchers' work methodologies in research units, universities, or other higher education institutions. From this standpoint, citizens and researchers shall establish a close partnership because they are part of the same team ${ }^{(20)}$.

At an international level, several initiatives have sought to increase the researchers' awareness of the citizens' potential to contribute to the development of research focused on the real needs of the citizens and the societies where they are inserted. These initiatives promote the acceptance and involvement of the citizen in scientific research in any area of knowledge, such as nursing, exact, natural, or social sciences in universities, research units, or businesses.

In this context, the structured action plan for citizen involvement in research processes of research units and universities involves (i) evaluating researchers' perceptions of citizen involvement in research processes; (ii) implementing measures to raise researchers' awareness of the importance of this involvement for improving research outcomes; (iii) establishing the moments for Citizen Involvement within the various research methodologies (experimental or quasiexperimental studies, epidemiological studies, systematic reviews); (iv) defining the citizen's profile based on the several methodologies and research areas/targets to be involved; (v) developing internal guidelines; and (vi) implementing initiatives to raise awareness and recruit members of society to actively engage in these co-created, co-designed, and co-validated processes ${ }^{(15,18)}$.

The citizen's role in research must be analyzed based on the types of involvement mentioned above. Considering that Citizen Involvement tends towards co-production partnerships, citizens can play several roles, such as (i) defining priority areas for study/development of products/services; (ii) working as project consultants or coordinators; (iii) collecting data from the sample under study; (iv) creating, analyzing, and disseminating information leaflets for patients/citizens; or (v) developing other knowledge dissemination materials ${ }^{(5,10)}$.

\section{ARGUMENTS TO SUPPORT CITIZEN INVOLVEMENT IN NURSING RESEARCH}

Citizen Involvement is the next step towards more meaningful research for the discipline of nursing and for societies. There are many arguments to support citizen involvement, partnership, and presence in research units/universities somehow related to our discipline. The quality brought into nursing research, the increased likelihood of a research/ product being successful, the sense of accountability and democracy, especially in publicly funded research, are among the strongest arguments for citizen involvement. For these reasons, funding bodies are increasingly encouraging some form of citizen involvement in the studies they fund ${ }^{(10,18)}$.

Therefore, Citizen Involvement in research units that develop health research in general and nursing research in particular should be encouraged, and action protocols should be established based on the several citizen profiles and research methodologies to be implemented. Nursing researchers should be aware that this involvement can (i) improve study design and participant recruitment, leading to greater study acceptability/participant adherence; (ii) assist the nursing research team in making the best decisions; (iii) facilitate the processes of dissemination of results and creation of materials related to the research process, such as protocols; (iv) give the researchers more confidence because it is easier to address the real needs of the populations; and (v) allow nursing researchers and their institutions to carry out studies and analyze data on a larger scale, with less costs ${ }^{(10,18,21)}$.

\section{Extension to Society}

Universities develop their mission in two major areas: education and research. Nevertheless, universities have always contributed to decision-making in society at large, which is increasingly becoming their third mission area, aiming to contribute to the interaction between universities and their organic units and the rest of society ${ }^{(22,23)}$.

Higher education institutions are asked to actively participate, on their own or through their organic units (such as research units), in activities that foster the connection to society with the purpose of disseminating and transferring knowledge, services, or products to the community. The Extension of the university to Society increases the 
economic value of scientific and technological knowledge and contributes to a better public understanding of science, technology, and the $\operatorname{arts}^{(22,23)}$.

The mission of researchers, research units, and universities in society is to make knowledge accessible, user-friendly, and easy to consume. Their other mission is to provide the best knowledge and products available to end-users (health professionals, citizens, and policymakers), for example, by synthesizing evidence (summaries of the best available knowledge) to promote informed decision-making in health at both individual and political levels. If, on the one hand, research units/universities are responsible for producing useful, relevant, and meaningful knowledge for society, on the other hand they are responsible for implementing it in the community. Therefore, Extension to Society can include all activities, projects, and initiatives that seek to increase the empowerment and literacy of citizens/communities and technological development ${ }^{(22-25)}$.

Extension to Society is a bilateral partnership, also called an engagement, between the members of society in general and the researcher in particular. It aims to make science, knowledge, and products/services available to society, users, and end-consumers, such as citizens, patients, nurses, or other professionals ${ }^{(24,25)}$.

\section{HOW TO IMPROVE THE EXTENSION TO SOCIETY}

Universities, their organic units, and the communities have been recreating themselves to bring science closer to society through (i) the promotion of experimental science education in primary and secondary schools to increase young citizens' interest in an artistic, scientific, and technological culture, (ii) the organization of scientific dissemination campaigns for the public in general, and (iii) the creation and promotion of centers for Active/Live/Open Science. For example, in Portugal, the Ciência Viva Program aims to bring science closer to society by developing several activities such as the Science and Technology Week, Ciência Viva Journeys, Ciência Viva at Home, Ciência Viva in the Summer, among others. In these activities, the Ciência Viva Program involves several institutions, such as research centers and universities ${ }^{(26)}$.

Research units and higher education institutions should generally seek to maintain this active engagement through (i) the participation of their researchers in science festivals open to society, (ii) the organization of scientific debates and discussions aimed at different target groups, (iii) the share of the best available knowledge on social networks, (iv) the synthesis of evidence on key issues using a simple language, (v) the implementation of projects in the communities, and (vi) the dissemination of study findings in social networks, newspapers, or television programs ${ }^{(22,23,27)}$.

\section{WHAT ARE THE GAINS FROM THE EXTENSION TO SOCIETY?}

According to the National Coordinating Centre for Public Engagement, Extension to Society describes the myriad of activities through which agents, such as higher education institutions or research units, can share their knowledge with society in a mutually beneficial relationship. Extension to Society is a two-way process involving interaction and listening to generate mutual benefit ${ }^{(24,25)}$. This mutually beneficial relationship is at the core of this Extension because a true engagement with society leads to favorable outcomes for primary, secondary, and tertiary end-users (outputs) and promotes SR\&TD projects (inputs). Some of these inputs/outputs include (i) the promotion of new learning experiences; (ii) the development of new ideas/insights; (iii) the development of new research areas; (iv) the improvement of services or products; (v) the promotion of citizen literacy; (vi) development and economic growth; (vii) and the emancipation of societies ${ }^{(21-25)}$.

Research units and universities that have contributed to the development of the nursing discipline recognize the benefits of Extension activities. Through these activities, these structures of knowledge contribute, in an organized and systematic way, to the social affirmation of the knowledge produced/products developed in society. Moreover, in this area of Extension to Society, the research units integrated into universities have increased responsibility. Universities and other higher education institutions aim to be an interdisciplinary, educational, cultural, scientific, and political arena where education, research, and extension to society should work together ${ }^{(28,29)}$.

In short, many research units and universities have steps toward a more informed society. Extension activities promote the development of researchers and research teams and, consequently, of research units and universities. They also provide access to the best available knowledge, promote best practices/services, and increase the health literacy of the citizen/community. This "machine" offers extensive economic and social benefits to the economic development of a country. Therefore, they are unique contributions offered by an increasingly Open Science, also called Citizen Science ${ }^{(18,27)}$. The concept of Citizen Science is based on the involvement of citizens as active research members to increase scientific knowledge production - "productivity view" - and bridge the gap between science and society in general - "democratization view"(30).

\section{FINAL CONSIDERATIONS}

Research units, universities, and other higher education institutions that systematically promote SR\&TD and Innovation are dynamic structures constantly adapting to the demands and needs of society. This society represents every citizen, every professional, every patient, and every end-user.

Citizen Involvement and Extension to Society should be strategic development areas of any research unit or university. Citizen Involvement in research is a best practice that should be promoted to respond to the actual needs of society. On the other hand, Extension to Society is a social responsibility of universities and their organic units that generates mutual benefits to all those involved (citizen and university).

In summary, this theoretical-reflective article aimed to clarify and operationalize concepts and, consequently, helped to understand the meaning of the Extension of the knowledge of universities or research units to Society and 
Citizen Involvement in developing SR\&TD participation and co-production methods. Throughout the development of the nursing discipline, it is important to involve citizens in research processes and promote Extension to Society, thus contributing to a more transparent, accessible, applicable science that addresses the needs of society in general.

\section{RESUMO}

Investigação de alta qualidade em saúde deve envolver o cidadão, pois promove mérito, relevância e valor às atividades de investigação e assegura a transferência de novos conhecimentos ou resultados para a comunidade. Este estudo teórico teve como objetivo conceituar e discutir o Envolvimento do Cidadão nos processos de investigação e Extensão à Sociedade dos seus resultados, revelando que ambos os conceitos têm finalidades distintas. Unidades de investigação e agências de financiamento incentivam o Envolvimento do Cidadão em todas as etapas do processo de pesquisa, acreditando-se que o mesmo adiciona qualidade aos processos de pesquisa. Por outro lado, universidades, unidades de investigação e pesquisadores têm a responsabilidade social de estenderem seus conhecimentos à sociedade, aos cidadãos ou aos usuários finais. O Envolvimento do Cidadão e a Extensão à Sociedade devem ser considerados áreas estratégicas para o desenvolvimento da pesquisa em geral e da enfermagem em particular. Estudos que envolvam o cidadão são necessários para gerar novos conhecimentos e produtos úteis para melhor atender às reais necessidades da sociedade.

\section{DESCRITORES}

Ciência do Cidadão; Participação da Comunidade; Relações Comunidade Instituição.

\section{RESUMEN}

La investigación en salud de alta calidad debe involucrar el ciudadano, aportar mérito, relevancia y valor a la investigación y garantizar la transferencia de nuevos conocimientos o resultados para la comunidad. Este estudio teórico tuvo como objetivo conceptuar y debatir el rol de la Intervención Ciudadana y de la Extensión a la Sociedad en los procesos y conclusiones de investigación, revelando que ambos los conceptos tienen finalidades distintas. Unidades de investigación y agencias de fomento a la investigación han promovido la Intervención del Ciudadano en todas las etapas del proceso de investigación una vez que ella aporta calidad a los mismos. Por otro lado, universidades, unidades de investigación e investigadores deben "extender" sus conocimientos a la sociedad, a los ciudadanos o a los usuarios finales como parte de su responsabilidad social. La Intervención del Ciudadano y la Extensión a la Sociedad deben ser consideradas áreas estratégicas para el desarrollo de la investigación en enfermería, específicamente. Más estudios son necesarios para generar nuevos conocimientos y productos útiles con la finalidad de atender mejor a las necesidades de la sociedad.

\section{DESCRIPTORES}

Ciencia Ciudadana; Participación de la Comunidad; Relaciones Comunidad-Institución.

\section{REFERENCES}

1. European Commission. Science, Research and Innovation performance of the EU - A contribution to the Open Innovation, Open Science, Open to the World agenda. Brussels: European Commission; 2016.

2. Oliveira L, Carvalho A. Public Engagement with Science in Portugal and Spain: Evolution and Current Status. Pinto-Coelho Z, Fidalg J, editors. About Communication and Culture: I Doctoral Student Days in Communication Sciences and Cultural Studies. Braga: Universidade do Minho: Centro de Estudos de Comunicação e Sociedade; 2012. p. 15-36.

3. Aristeidou M, Scanlon E, Sharples M. Profiles of engagement in online communities of citizen science participation. Comput Human Behav. 2017;74:246-56. DOI: http://dx.doi.org/10.1016/j.chb.2017.04.044.

4. Ocloo J, Garfield S, Franklin BD, Dawson S. Exploring the theory, barriers and enablers for patient and public involvement across health, social care and patient safety: a systematic review of reviews. Heal Res Policy Syst. 2021;19(1):8.

5. South A, Hanley B, Gafos M, Cromarty B, Stephens R, Sturgeon K, et al. Models and impact of patient and public involvement in studies carried out by the Medical Research Council Clinical Trials Unit at University College London: Findings from ten case studies. Trials. 2016;17(1). DOI: http://dx.doi.org/10.1186/s13063-016-1488-9.

6. Tembo D, Hickey G, Montenegro C, Chandler D, Nelson E, Porter K, et al. Effective engagement and involvement with community stakeholders in the co-production of global health research. BMJ. 2021;372:178.

7. Wale JL, Thomas S, Hamerlijnck D, Hollander R. Patients and public are important stakeholders in health technology assessment but the level of involvement is low - a call to action. Research Involvement and Engagement. 2021;7(1):1-11.

8. Norburn L, Thomas L. Expertise, experience, and excellence. Twenty years of patient involvement in health technology assessment at NICE: an evolving story. Int J Technol Assess Health Care. 2021;37:e15.

9. European Commission. Public Engagement and responsible research and innovation [Internet]. 2020 [cited 2021 Feb 12]. Available from: https://ec.europa.eu/programmes/horizon2020/en/h2020-section/public-engagement-responsible-research-and-innovation\#Article.

10. Bonney R, Ballard H, Jordan R, Mccallie E, Phillips T, Shir J, et al. Public Participation in Scientific Research: Defining the Field and Assessing Its Potential for Informal science Education. Washington: Education Resources Information Center; 2009. ERIC Number: ED519688.

11. Miller-Rushing A, Primack R, Bonney R. The history of public participation in ecological research. Front Ecol Environ. 2012;10(6): 285-90. DOI: http://doi.wiley.com/10.1890/110278.

12. Bonney R, Cooper CB, Dickinson J, Kelling S, Phillips T, Rosenberg KV, et al. Citizen Science: A Developing Tool for Expanding Science Knowiedge and Scientific Literacy. Roundtahle. 2009;59(11)977-84.

13. Vale C, Fitzgibbo J, Hanley B, Muir D, Murphy C, Nelson A, et al. Public involvement in clinical trials: Supplement to the briefing notes for researchers. Eastleigh: INVOLVE; 2012.

14. Vale C, Gyte G, Hanley B, Humphrys R, Mcllwain C, Popay J, et al. Public involvement in systematic reviews: Supplement to the briefing notes for researchers. Eastleigh: INVOLVE; 2012. 
15. Vale CL, Thompson LC, Murphy C, Forcat S, Hanley B. Involvement of consumers in studies run by the Medical Research Council Clinical Trials Unit: Results of a survey. Trials. 2012;13(1):9.

16. National Institutes of Health [internet]. Public Involvement with NIH. Bethesda: National Institutes of Health; 2020. Available from: https://www.nih.gov/about-nih/what-we-do/get-involved-nih/public-involvement-nih.

17. Cochrane. An international network for public involvement and engagement in health and social care research [Internet]. 2018 [cited 2021 Feb 13]. Available from: https://www.cochrane.org/news/international-network-public-involvement-and-engagement-health-andsocial-care-research.

18. Lakomý M, Hlavová R, Machackova H, Bohlin G, Lindholm M, Bertero MG, et al. The motivation for citizens' involvement in life sciences research is predicted by age and gender. PLoS One. 2020;15(8):e0237140.

19. Patient innovation [Internet]. Soluções mais recentes. Lisboa: Instituto Bacteriológico; 2021 [cited 2021 Mar 3]. Available from: https:// patient-innovation.com/?language=pt-pt.

20. Ward F, Popay J, Porroche-Escudero A, Akeju D, Ahmed S, Cloke J, et al. Mainstreaming public involvement in a complex research collaboration: A theory-informed evaluation. Heal Expect. 2020;23(4):910-8.

21. Marschalek li. Public Engagement in Responsible Research and Innovation - A Critical Reflection from the Practitioner's Point of View [Dissertation]. Vienna: University of Vienna; 2017.

22. Carl J, Menter M. The social impact of universities: assessing the effects of the three university missions on social engagement. Stud High Educ. 2021;46(5):1-12.

23. Perkmann M, Salandra R, Tartari V, McKelvey M, Hughes A. Academic engagement: A review of the literature 2011-2019. Res Policy. 2021;50(1):104114.

24. Wellcome Trust. Developing a Strategic Approach to Public Engagement in the Wellcome Trust's UK Centres - Public Engagement workshop report [Internet]. Londres: Wellcome Trust; 2014. Available from: https://www.wellcome.ac.uk/stellent/groups/corporatesite/ $@$ @msh_peda/documents/web_document/.

25. National Co-ordinating Centre for Public Engagement [internet]. Bristol: National Co-ordinating Centre for Public Engagement; 2020 [cited 2021 Jan 12]. What is public engagement? Available from: https://www.publicengagement.ac.uk/about-engagement/what-publicengagement.

26. Ciência Viva [Internet]. Lisboa: Ciência Viva; 2021 [cited 2021 Mar 6]. Rede de Centros Ciência Viva. Available from: https://www. cienciaviva.pt/.

27. Dandoy JP. Partnership \& Place-Based Community Engagement: Competencies and Contributions of Professionals Within an Emerging Field. Dissertation - Doctor of Education, School of Education - University of Pittsburgh. 2020.

28. Silva ALB, Sousa SC, Chaves ACF, Sousa SGC, Filho DRR. Importance of University Extebsion in Vocational training: Canudos Project. J Nurs UFPE. 2019;13:e243189.

29. Archibald MM, Barnard A. Futurism in nursing: Technology, robotics and the fundamentals of care. J Clin Nurs. 2018;27(11-12):2473-80.

30. Sauermann H, Vohland K, Antoniou V, Balázs B, Göbel C, Karatzas K, et al. Citizen science and sustainability transitions. Res Policy. 2020;49(5):103978.

\section{Financial support}

National Funds through the FCT - Foundation for Science and Technology, I.P., within the scope of the project Ref. UIDB/00742/2020. 